\title{
Successful recanalization of total chronic occlusion of the superficial femoral artery by antegrade subintimal angioplasty with stenting using the Pioneer Plus Re-Entry Catheter
}

Udana rekanalizacja przewlekłej całkowitej okluzji tętnicy udowej powierzchownej poprzez angioplastykę subintimalną ze stentowaniem przy użyciu cewnika Pioneer Plus Re-Entry

\author{
Radosław Szymański ${ }^{1}$, Szymon Wiernek1, Barbara Wiernek², Magda Konkolewska', Paweł E. Buszman², \\ Radosław S. Kiesz ${ }^{1}$
}

1San Antonio Endovascular \& Heart Institute, San Antonio, TX, USA

2American Heart of Poland, Katowice, Poland

Post Kardiol Interw 2011; 7, 1 (23): 91-94

DOI: 10.5114/pwki.2011.21196

\begin{abstract}
The subintimal angioplasty is one of the most frequent techniques used for total chronic occlusion (CTO) treatment. Nevertheless, this approach is limited by the lack of controlled re-entry into the true lumen of the target vessel. We present a case of a 85-yearold man with symptomatic CTO of the left superficial femoral artery (SFA). After initially unsuccessful subintimal recanalization with Confianza wire, Pioneer Plus Catheter with Intravascular Ultrasound Volcano system guidance were used for a true lumen re-entry. Finally lesion was treated with angioplasty and stents. Procedure was successful without complications, no residual stenosis was noted. The patient was discharged home four hours after procedure. The one day and three weeks follow up showed no vascular complications and the patient had no residual symptoms. The ankle-brachial index of the left extremity has improved from baseline 0.22 to 0.98 .
\end{abstract}

Key words: re-entry catheter, subintimal angioplasty, total chronic occlusion (CTO), superficial femoral artery (SFA)

\section{Streszczenie}

Subintimalna angioplastyka jest jedną z najczęściej stosowanych technik podczas leczenia przewlekłych całkowitych okluzji tętnic kończyny dolnej (СTO). Metoda ta jest jednak ograniczona brakiem kontroli nad powrotem do prawdziwego światła naczynia. Prezentujemy przypadek 85-letniego mężczyzny z objawami CTO w lewej tętnicy udowej powierzchownej (SFA). Po nieudanym początku rekanalizacji subintimalnej prowadnikiem Confianza, cewnik Pioneer Plus z systemem ultrasonografii wewnątrznaczyniowej Volcano został wykorzystany do powrotu do prawdziwego światła naczynia. Ostatecznie do zaopatrzenia zmiany zastosowano angioplastykę i stentowanie. Procedura zakończyła się pomyślnie, bez powikłań, nie stwierdzono zwężenia rezydualnego. Mężczyzna został wypisany do domu po 4 godz. po zabiegu. W trakcie jednodniowej i 3-tygodniowej obserwacji nie stwierdzono powikłań naczyniowych, a pacjent nie zgłaszał pozostałych objawów. Wskaźnik kostkowo-ramienny lewej kończyny poprawił się z wartości wyjściowej 0,22 do 0,98 .

W niniejszym artykule przedstawiono cewnik Pionieer Plus z systemem ultrasonografii wewnątrznaczyniowej, którym uzyskano światło prawdziwe tętnicy udowej powierzchownej (SFA), a następnie przeprowadzono angioplastykę ze stentem, uzyskując dobry efekt angiograficzny oraz kliniczny.

Słowa kluczowe: cewnik re-entry, angioplastyka subintimalna, przewlekła całkowita okluzja tętnic kończyny dolnej, tętnica udowa powierzchowna

Corresponding author/Adres do korespondencji:

Radosław Szymański MD, San Antonio Endovascular \& Heart Institute, 18615 Tuscany Stone, Suite 170, San Antonio, TX 78 258, USA,

e-mail: rszymanski@drkiesz.com

Praca wpłynęła 22.11.2010, przyjęta do druku 20.02.2011. 


\section{Introduction}

New techniques and device technologies have improved the success rates of treating peripheral chronic total occlusions (CTO). An important role is played by subintimal angioplasty, which is an effective and useful method for total chronic occlusions of the superficial femoral artery (SFA) treatment [1], especially when combined with true lumen reentry devices [2-4]. This report shows the efficacy and safety of the Pioneer Plus Re-Entry Catheter in re-entering the distal true lumen during intervention of a chronic total occlusion of the SFA in a patient with severe critical limb ischaemia.

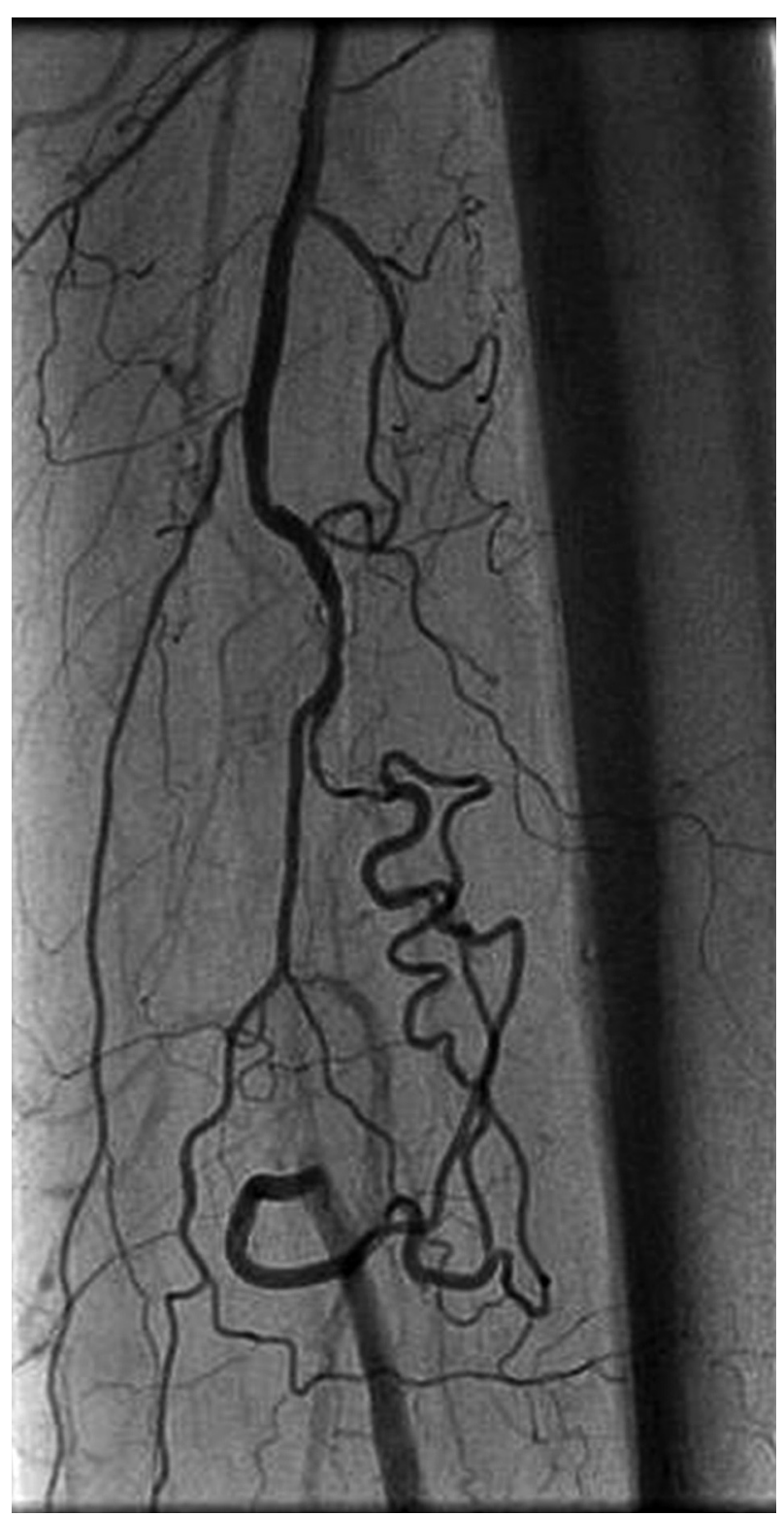

Fig. 1. Total occlusion of the left superficial femoral artery (SFA)

Ryc. 1. Przewlekła catkowita okluzja lewej tętnicy udowej powierzchownej (SFA)

\section{Case report}

An 85-year-old man presented with a long-term medical history of disabling claudication and abnormal pulse volume recordings (PVR). His left ankle-brachial index was 0.22 . The patient had a history of coronary artery disease, pacemaker insertion, non-insulin dependant diabetes, smoking, hypertension and hyperlipidaemia. One month prior this procedure, patient underwent a successful percutaneous transluminal angioplasty (PTA) and stenting of the right iliac artery and right SFA. Because of persistent disabling claudication in the left lower extremity he returned for percutaneous treatment of the chronically occluded left SFA. A 6 F sheath was inserted in antegrade fashion into the left superficial artery. Guiding angiograms of the left lower extremity were taken. They revealed a flush occlusion of the mid proximal SFA with reconstruction in Hunter's canal (fig. 1). Using a Confianza wire with a support catheter, a total occlusion was crossed subintimally (fig. 2), but attempts to re-enter the true lumen were unsuccessful. Therefore a Pioneer Plus Catheter with Intravascular Ultrasound Volcano system guidance were used to reenter the lumen (fig. 3). Angioplasty of CTO was performed using a $5.0 \times 60 \mathrm{~mm}$ VascuTrak balloon with several overlapping inflations. Subsequently stenting with $6.0 \times 150 \mathrm{~mm}$ and $6.0 \times 80 \mathrm{~mm}$ selfexpandable nitinol stents was performed. The distal stent was additionally post-dilated with a $5.0 \times 60$ VascuTrak balloon at 6 atmospheres. No residual stenosis and no dissection after stenting were observed (fig. 4). The patient reported a warm sensation in the left foot. Previously non-palpable posterior tibial and dorsalis pedis pulses were now +3 and +1 respectively. At the end of the intervention, a vascular closure device was applied. Four hours after the procedure the patient was discharged home. The follow-up performed one day and three weeks after the procedure showed no vascular complications and the patient had no residual symptoms. The left ankle-brachial index has improved to 0.98 .

\section{Discussion}

Endovascular treatment of peripheral artery disease including SFA has evolved with increasing physician experience and new technologies. Percutaneous angioplasty of the SFA or stenting are associated with suboptimal long term clinical outcomes [5]. Studies revealed that short lesions $(<5 \mathrm{~cm})$ in the SFA respond well to balloon angioplasty alone, with primary and secondary patency rates comparable to stenting. Therefore, stenting of the SFA is generally indicated only in the presence of a flow limiting dissections or severe elastic recoils [5]. Also, a recent randomized controlled clinical trial, in which patients with long SFA lesions (mean length $13 \mathrm{~cm}$ ) were enrolled, showed that stenting with SE nitinol stents brings benefit in lower rates of restenosis in 6-month observation compared with balloon angiography alone ( $24 \%$ stent vs. 


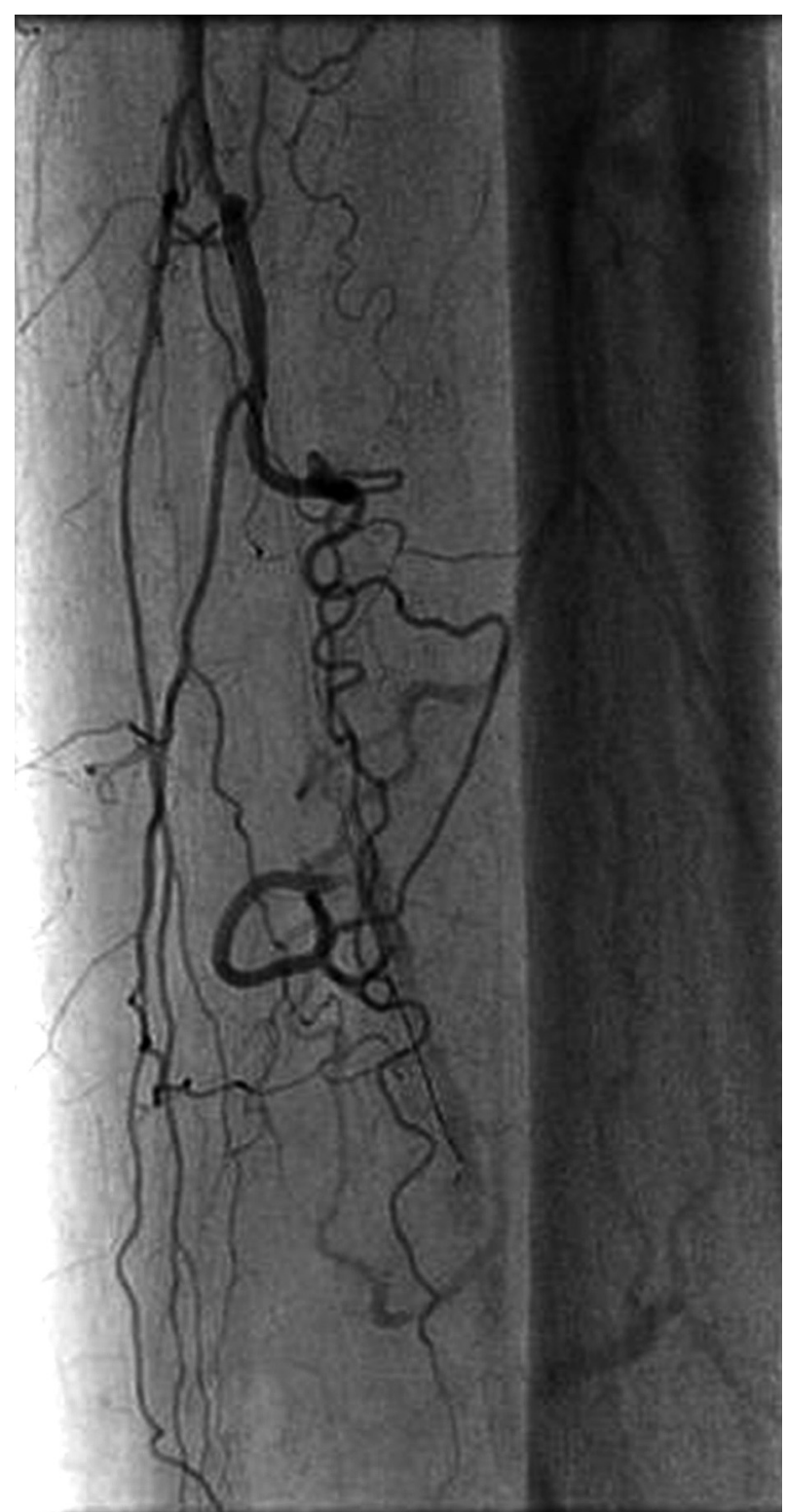

Fig. 2. Subintimal wiring for occlusion using the Confianza wire with support catheter

Ryc. 2. Prowadnik Confianza i cewnik wspomagajacy w przestrzeni subintimalnej podczas angioplastyki

43\% balloon angiography, $p=0.05$ ] [6]. In presented case, after balloon angioplasty, we observed a small dissection with a slow flow, therefore we decided to use a long selfexpandable nitinol stent. However, in the majority of patients with atherosclerosis of the SFA, the disease is often diffused, and is associated with chronically occluded segments and often involves the region of the adductor canal. There stents often fracture due to constant flexion, elongation and torsion during routine daily activities [5, 7]. One of the most challenging problems for interventionalists treating patients with peripheral artery disease is crossing the CTO. Subintimal angioplasty is one of the most frequent

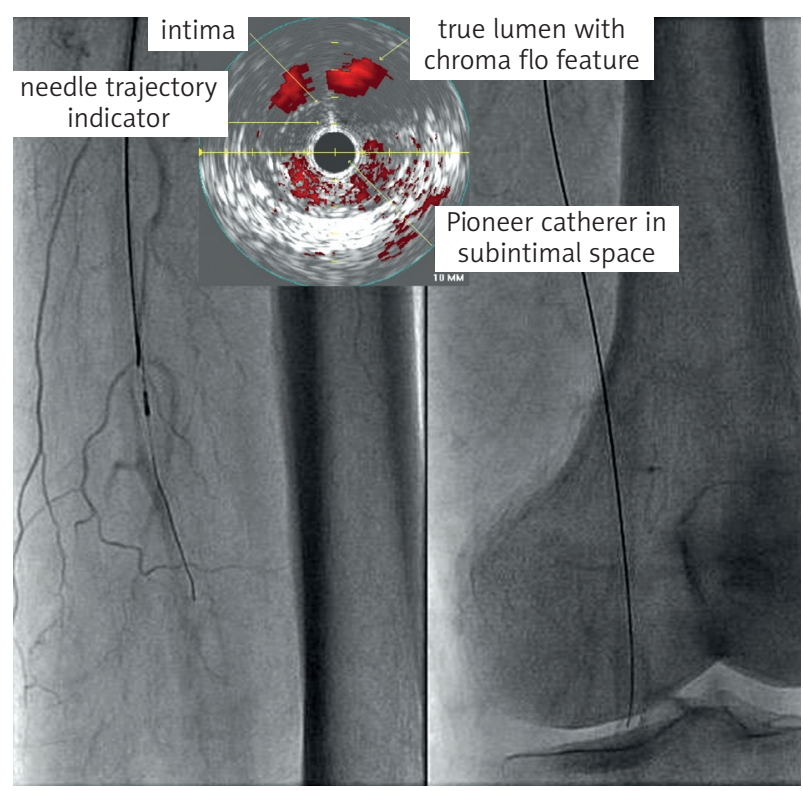

Fig. 3. True lumen revealed using Pioneer Plus Catheter and Volcano System Guidance

Ryc. 3. Prawdziwe światło naczynia uzyskane przy pomocy cewnika Pioneer Plus i systemu ultrasonografii wewnątrznaczyniowej Vulcano

techniques used for treatment of CTO. However, this method is often associated with inability to re-enter the true lumen, distally to occlusion, 13-26\% [3] (tab. 1). Single centre studies showed that using re-entry devices, the true lumen can be reached in $95-100 \%$ of cases [8] (tab. 2). This would suggest that a high percentage of patients with CTO could avoid bypass grafts, which is especially important for high-risk surgical patients. Although repeat endovascular interventions are necessary to maintain patency, the outpatient nature of these procedures would allow improved quality of life compared to surgical interventions [9]. Recently, numerous re-entry devices have become available for use in the peripheral vasculature but none of these devices has been tested in randomized clinical trials [5]. The Pioneer Catheter is designed to facilitate subintimal angioplasty of the peripheral vasculature using intravascular ultrasound (IVUS) imaging for re-entry to the true lumen and was the first device to address a problem associated with subintimal angioplasty [2]. Most of the devices use only fluoroscopy guidance for re-entry to the true lumen, which provides only very limited information since the orientation of the catheter and the correct trajectory to regain the true lumen are not obvious. In the present case, we used the Pioneer Plus (Medtronic), monorail, Dual-Wire (0.014 inch) System. The carved needle at the end of the catheter may be advanced to an adjustable depth. The length of the catheter is $120 \mathrm{~cm}$. This device is also integrated with intravascular ultrasound to allow for real time imaging at the time of needle deployment for re-entry into the true lumen. The Pioneer Plus catheter can be used only with the Volcano Imaging 


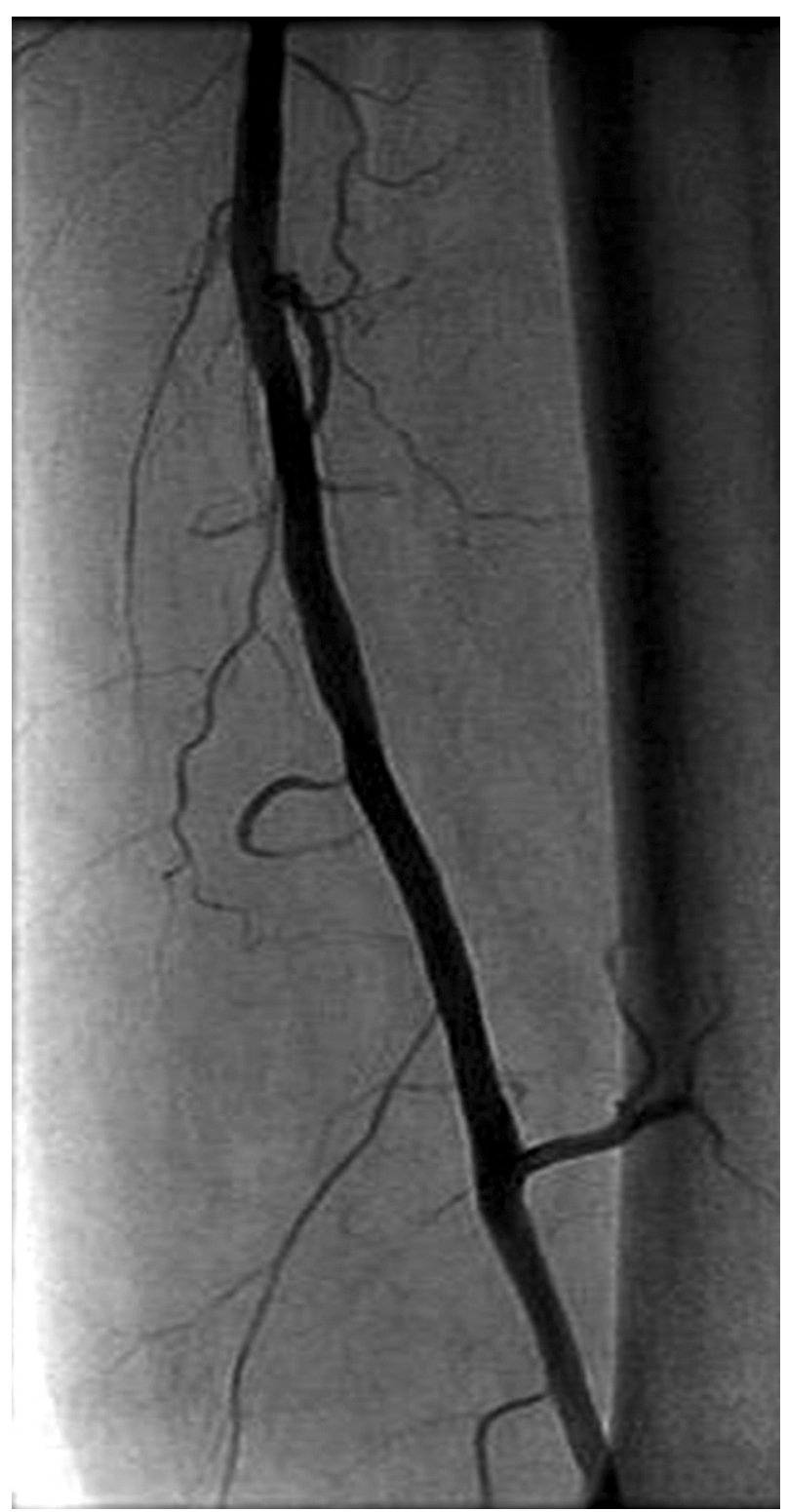

Fig. 4. Final result after stenting deployment. Angiography shows a large, widely patent left superficial artery (SFA)

Ryc. 4. Rezultat końcowy po angioplastyce i stentowaniu. Angiografia uwidacznia dużą, drożną tętnice powierzchowna uda (SFA)

System and is not compatible with other imaging systems, which is a limitation to its use. An alternative for centres which are not equipped with a specific IVUS system is the Outback Catheter (Cordis), which also has an extendable curved needle for lumen reentry but does not use IVUS guidance [8]. Other CTO devices, such as Wildcat, may obtain permission in the near future. In conclusion, the Pioneer Plus Catheter is a safe, effective re-entry device that improves technical success of subintimal angioplasty, which may lead to improvement in the care of patients with CTOs.
Table 1. Success and patency rates of subintimal angioplasty alone [8]

Tabela 1. Skuteczność zabiegu oraz drożność naczynia po samej angioplastyce subintimalnej [8]

\begin{tabular}{lccc} 
& $\begin{array}{c}\text { Success } \\
\text { rates [\%] }\end{array}$ & $\begin{array}{c}\text { Follow-up } \\
\text { [months] }\end{array}$ & $\begin{array}{c}\text { Patency } \\
\text { rate [\%] }\end{array}$ \\
\hline London et al. & 80 & 12 and 36 & $\begin{array}{r}71 \text { and 58, } \\
\text { retrospect. }\end{array}$ \\
\hline McCarthy et al. & 74 & 6 & 77 \\
\hline Lipsitz et al. & 87 & 12 & 74 \\
\hline Tartari et al. & 85 & 6 & 70
\end{tabular}

Table 2. Success rate of subintimal angioplasty using the Pioneer Catheter (Medtronic, Inc.) [8] Tabela 2. Skuteczność zabiegu angioplastyki subintimalnej w polaczeniu z systemem Pioneer Plus (Medtronic, Inc.) [8]

\begin{tabular}{llcc} 
& Type of study & $n$ & Success rate [\%] \\
\hline Casserly et al. & Case report & 2 & 100 \\
\hline Jacobs et al. & Case series & 21 & 100 \\
\hline Saket et al. & Case series & 7 & 100 \\
\hline Hazim Al-Ameri et al. & Case series & 21 & 95
\end{tabular}

\section{References}

1. Choi JH. Successful recanalization of long superficial femoral artery occlusion by retrograde subintimal angioplasty after a failed antegrade subintimal approach. Korean Circ J 2008; 38: 557-560.

2. Al-Ameri H, Shin V, Mayeda GS, et al. Peripheral chronic total occlusions treated with subintimal angioplasty and a true lumen re-entry device. J Invasive Cardiol 2009; 21: 468-472.

3. Casserly IP, Sachar R, Bajzer C, Yadav JS.. Utility of IVUS-guided transaccess catheter in the treatment of long chronic total occlusion of the superficial femoral artery. Catheter Cardiovasc Interv 2004; 62: 237-243.

4. Latacz P, Pieniazek P, Rostoff P, et al., Subintimal recanalisation of chronic superficial femoral artery occlusion with the use of a reentry system [Polish]. Kardiol Pol 2008; 66: 1121-1125; discussion 1126.

5. Mahmud E, Cavendish JJ, Salami A. Current treatment of peripheral arterial disease: role of percutaneous interventional therapies. J Am Coll Cardiol 2007; 50: 473-490.

6. Schillinger M, Sabeti S, Loewe C, et al. Balloon angioplasty versus implantation of nitinol stents in the superficial femoral artery. N Engl J Med 2006; 354: 1879-1888.

7. Scheinert D, Scheinert S, Sax J, et al. Prevalence and clinical impact of stent fractures after femoropopliteal stenting. J Am Coll Cardiol 2005; 45: 312-315.

8. Al-Ameri H, Shin V, Mayeda GS, et al. Peripheral chronic total occlusions treated with subintimal angioplasty and a true lumen re-entry device. J Invasive Cardiol 2009; 21: 468-472.

9. Lee LK, Kent KC. Infrainguinal occlusive disease: endovascular intervention is the first line therapy. Adv Surg 2008; 42: 193-204. 